\title{
La doble lectura de Canciones para después de una guerra explicada desde el marco teórico de las problemáticas del documental
}

\section{González, Nerea}

Resumen: Este artículo es una aproximación teórica al documental Canciones para después de una guerra (1971), filmado por el realizador español Basilio Martín Patino durante los años finales del franquismo. En este filme, el director hace un retrato de la España de la posguerra a través de imágenes de archivo y canciones populares. A partir de los conceptos desarrollados por algunos de los principales pensadores del cine documental, se busca aportar nuevas consideraciones, en un sentido puramente teórico, que contribuyan a explicar un fenómeno curioso ocurrido en su recepción crítica y en la evaluación para su censura: no había acuerdo sobre si se trataba de una película antifranquista o de todo lo

Cuadernos del Centro de Estudios de Diseño y Comunicación N ${ }^{\circ} 62$

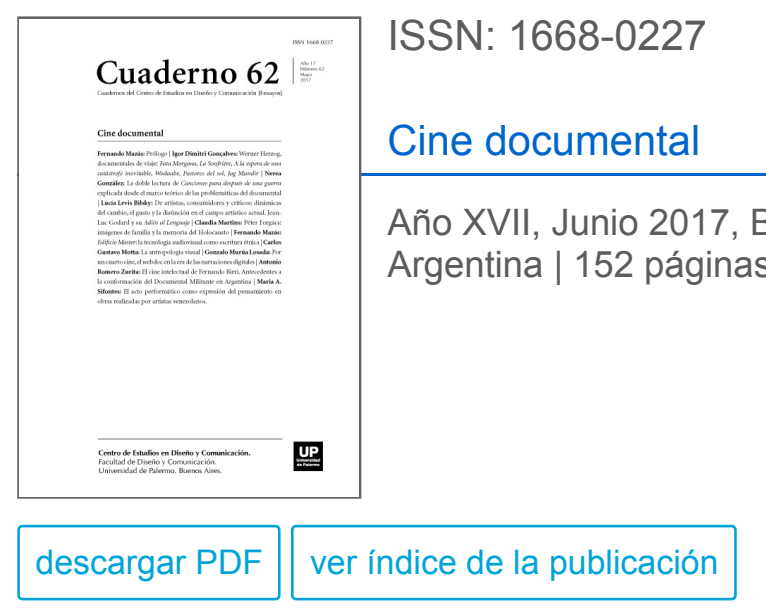

Ver todos los libros de la publicación

compartir en Facebook contrario. Las especificidades de la imagen documental, el discurso reflexivo de Patino opuesto a una aparente expositividad y el esfuerzo extra de interpretación que requiere esta película en comparación con el cine que tenía a su acceso en la época el público medio son algunos de los factores que abren, en nuestra opinión, un abanico de dificultades de recepción orgánicas al filme, previas a la mirada del espectador.

Palabras clave: Basilio Martín Patino - Canciones para después de una guerra - franquismo - España documental expositivo - reflexividad.

$\left(^{*}\right)$ Licenciada en Periodismo y Comunicación Audiovisual por la Universidad Carlos III de Madrid (UC3M). Titulada en el Máster de Periodismo de Agencia de la Universidad Rey Juan Carlos de Madrid (URJC). Corresponsal en Buenos Aires de la agencia de noticias española EFE. Alumna de la Maestría de Cine Documental de la Universidad del Cine (FUC). 
Este estudio pretende explicar desde un punto de vista teórico un fenómeno singular que ocurrió con el estreno de un documental realizado durante los años finales del franquismo en España. Se trata de Canciones para después de una Guerra, una película articulada a partir de canciones y montaje de material de archivo que retrata la evolución de la España de la primera década de la dictadura de Francisco Franco (que duró desde 1939 hasta 1975), realizado en el año 1971 por el director Basilio Martín Patino (Lumbrales, Salamanca, España, 1930).

La película fue prohibida y no pudo estrenarse oficialmente hasta muerto el dictador. Sin embargo, antes de su censura, fue foco de una tremenda discusión entre críticos, censores y militantes políticos hasta llegar a las más altas instancias del régimen, ya que no había consenso sobre si se trataba de una cinta simpatizante con el franquismo o por el contrario, abiertamente opositora. Martín Patino recibió las alabanzas de una parte de la crítica y de sectores del poder dictatorial por entender que se trataba de una encarnación de los valores que habían guiado a España tras la Guerra Civil y un retrato sentimental de los años de la posguerra. Desde la izquierda clandestina, también se llegó a entender por algunos como un ensalzamiento del franquismo. Sin embargo, otros sectores no la recibieron con esa perspectiva sino que entendieron que se trataba de una crítica feroz a las condiciones de vida miserables y trasnochadas en las que la dictadura había sumido a España. La película pasaba algunas instancias de censura y fue incluso enviada al festival de San Sebastián, pero allí fue rechazada y se dio aviso a altas esferas del régimen.

Por ejemplo, mientras que para Pedro Crespo, crítico de cine del diario falangista (el partido fascista español) Arriba se trataba de "una obra de arte ejecutada con un pudor y una minuciosidad increíbles y con una gracia, una ternura, una tristeza, una nostalgia y una alegría vitales: un magnífico exponente de la evolución del país”, para Félix Martialay, de la publicación también fascista El Alcázar, era una película "atrozmente parcialista" hecha por un "adulto encogido y canijo, agonizante y llorón".

En El Alcázar se publicaron nada menos que medio centenar de artículos destinados a destruir la cinta de Martín Patino. Ante la polémica, la película llegó a ser vista por el número dos de Franco, el almirante Carrero Blanco, quien al finalizar la proyección amenazó con fusilar al director.

¿Por qué una obra como Canciones para después de una guerra puede suscitar interpretaciones completamente antagónicas? ¿Qué circunstancias pueden dar pie a que agentes entrenados precisamente para censurar las obras, con ojo crítico y con estricto respeto a los valores franquistas, lean esta película como una oda sentimental a la España del franquismo? Estas preguntas ya han sido respondidas por múltiples autores desde el punto de vista del análisis semántico de la película. También ha sido categorizada como documental, dentro de los llamados montajes irónicos, y se han estudiado los elementos audiovisuales no prohibidos que usó el autor para manipular a la audiencia.

No interesará por tanto a esta monografía diseccionar los detalles del discurso de Martín Patino, que son además inseparables de su relación con el conocimiento de la historia y la cultura de la España de ese periodo. Lo que se intentará aquí es explicar esta posibilidad de hacer dos lecturas antagónicas de la película desde el punto de vista de las características particulares del cine documental, es decir, dar una explicación teórica de este fenómeno a través de las problemáticas particulares de este tipo de cine. Además, consideramos que a través de esta obra podemos analizar varios de los debates históricos más significativos sobre el cine y la imagen documental. 
Expositividad y reflexividad

Vamos a defender, en primer lugar, al igual que ya lo han hecho otros autores (García Martínez, 2007) que Canciones para después de una Guerra se presenta como un documental expositivo, en el sentido de la taxonomía establecida por Bill Nichols en La representación de la realidad. Cuestiones y conceptos sobre el documental (Nichols, 1991). Pero también es un film reflexivo, que cuestiona las convenciones del discurso documental franquista tradicional.

Nichols caracteriza la modalidad expositiva con rasgos como la utilización de una voz en off dominante -la denominada "voz de Dios"- que dirige el discurso, ofrece escaso margen para la ambigüedad o la disensión y es preeminente sobre las propias imágenes.

La modalidad expositiva interpela al espectador y crea una continuidad retórica dirigida a exponer y demostrar un cierto argumento. No predomina el sonido directo o sincronizado y no suele haber entrevistas o testimonios directos (si los hay estarán destinados a reforzar el discurso). Hay una primacía del discurso sobre la imagen, de modo que es la voz la que asienta el sentido de la película e importa menos el hecho de que esta se corresponda o no con la imagen, que el hecho mismo de que se sitúa "por encima" de ella. En este sentido, Nichols apuntaba que la expositividad introduce problemas éticos derivados precisamente de las capacidades manipulativas que caracterizan la modalidad y de hecho es el estilo característico, por ejemplo, de los films de propaganda bélicos.

En Canciones para después de una guerra no hay una "voz de Dios" articulada como informe expositivo en un sentido ortodoxo, basado en la palabra, pero, en nuestra opinión, las canciones articulan de hecho un "comentario dirigido hacia el espectador" y las imágenes sirven como "ilustración o contrapunto" a ese texto, tal y como determina Nichols para caracterizar la modalidad expositiva (Nichols, 1991). Son las canciones populares las que configuran un discurso sobre la coyuntura de la España de la posguerra. Las canciones elegidas por Martín Patino hablan desde la victoria de los militares sublevados al hambre, la organización social de la época, el papel de las mujeres en la vida civil, la cultura y las costumbres de la época o la transformación progresiva en una sociedad de consumo. No son una simple banda sonora que acompaña a las imágenes sino los argumentos del realizador para cuestionar, a través de la ironía, el discurso oficial franquista.

Cabe mencionar que en algunas ocasiones sí que interviene una voz propiamente dicha, pero o bien se trata del off original que acompaña a los fragmentos de imágenes montados (como algunos extractos del Noticiario Documental Cinematográfico franquista, NO-DO) o bien de una voz poética grabada ex profeso que poco tiene que ver con la expositividad.

Dado que lo que pretende Martín Patino es que el espectador confronte sus ideas con lo que ve para que llegar a sus propias conclusiones gracias al montaje irónico, debemos hablar también de rasgos de reflexividad en el film, de nuevo, en el sentido de las modalidades de Nichols. El mismo autor apuntaba a la hora de exponer su taxonomía que las modalidades no aparecen de una forma pura, sino que se mezclan entre ellas.

En el caso de la modalidad reflexiva, "la representación del mundo histórico se convierte en sí misma en el tema de meditación cinematográfica" y gracias a la "conciencia de la forma y la estructura y de sus efectos determinantes" se pueden crear otras nuevas "no solo en teoría o estéticamente, sino en la práctica, 
socialmente" (Nichols, 1991). Además, hay distintas formas de reflexividad, como la política que hace referencia a esa forma más amplia de conciencia situada en un contexto social o la formal, que tiene que ver más con el dispositivo seleccionado y requiere un cierto conocimiento sobre las convenciones documentales.

A su vez, Bill Nichols enumera distintas estrategias de reflexividad. Estas son la estilística, que quebranta las normas estilísticas convencionales; la deconstructiva consistente en alterar los códigos de representación dirigiendo la atención del espectador hacia su convencionalismo; la interactividad, porque toda modalidad de representación puede ejercer un efecto de concienciación al dirigir la vigilancia del espectador hacia la excentricidad de filmar de una determinada manera; la ironía, ya que lo que se dice abiertamente no es lo que se quiere decir; y por último la parodia y la sátira, porque detonan la toma de conciencia de una determinada actitud o práctica social.

En Canciones para después de una guerra el director lleva a cabo un trabajo de montaje irónico con imágenes de archivo para crear un discurso nuevo. Es decir, elabora la película a través de la compilación de materiales preexistentes, que no fueron filmados con el objetivo de formar parte de este documental pero que aquí sirven para realizar una interpretación sobre el mundo histórico al que se refieren. Su objetivo es hablar dar una cierta visión sobre lo que fue España tras el final de la Guerra Civil española, durante la más dura posguerra (expositividad), pero a la vez consigue que el espectador cuestione o tome conciencia de las convenciones del discurso franquista, tanto las relativas al relato "oficial" sobre la historia como sobre el propio lenguaje audiovisual empleado por el régimen (reflexividad).

En un país donde el cine y más aún, las imágenes reales, estaban sometidas a un estricto control del Estado, Martín Patino retrata España como no la contaba el relato franquista, una historia de la gente de a pie y su dura vida diaria. El realizador pretende, a través de distintos mecanismos (como la ordenación de los materiales, el contraste imagen-sonido, etc.), que el espectador vaya en su lectura más allá de la literalidad de las imágenes o del consabido discurso oficial.

Martín Patino apela a conocimientos comunes presentes en el imaginario del público: por un lado, el discurso oficial del franquismo sobre la victoria ante el "enemigo comunista", la grandeza del pasado histórico de España, los progresos sociales y económicos que llegaron de la mano del régimen militar, etc. y por el otro las "inocentes canciones" populares que todo el mundo conoce. Sin embargo, gracias al montaje y la acumulación, la película va reescribiendo el significado de esos recursos y estructuras para poner en cuestión la visión de la historia de España que la propaganda franquista ha buscado instalar durante décadas: lo que se vivió fue hambre, atraso cultural, marginación de la comunidad internacional, etc.

El director utiliza casi exclusivamente de material de archivo que comprende desde metraje encontrado a material fotográfico, documentos, cromos y cartelería, fragmentos de películas de ficción, anuncios publicitarios, audios de la radio e imágenes televisivas, etc. La única excepción es el fragmento rodado para la película en el que podemos ver la imagen contemporánea de la cantante Estrellita de Castro (García Martínez, 2007), para contrastarla con las imágenes de archivo de la misma persona en su juventud, cuando era un exponente de la cultura española en pleno apogeo. En los casos puntuales en los que introduce extractos de películas que suponen claramente un hiato ficcional, consideramos que Patino las intercala como documentos que dan un testimonio cultural. Es decir, tienen el mismo estatuto aquí que una fotografía de la portada de un periódico o una imagen publicitaria porque hablan de la sociedad de un periodo concreto. El uso de las imágenes de ficción, 
así como de casos puntuales en los que empleó imágenes no pertenecientes a España, se abordará en profundidad en un apartado posterior de este estudio.

Se trata en todo caso de fuentes previamente aprobadas por la censura, cuando no directamente pertenecientes a la propaganda de la propia dictadura, cuyo significado se reescribe en la película a través del montaje. Podemos identificar así tres niveles: la imagen índice, su interpretación convencional oficial (derivada del discurso franquista) y su reinterpretación irónica dentro del enunciado propuesto por Martín Patino.

Al igual que indicaba Schaeffer (1990) para la interpretación de la fotografía, consideramos las imágenes reales en movimiento como índices en su "primer" estadio, como signos materiales no convencionales resultado de un proceso físico químico.

Si afirmo que la imagen fotográfica es un signo no convencional, no por ello esto me obliga a afirmar su perfecta transparencia. La interpretación de los signos naturales, como la de los signos convencionales, solo es posible en el contexto de cierto saber. Además de un saber sobre el mundo, también hay que disponer del saber del arché: una fotografía funciona como una imagen indicial con la condición de que sepamos que se trata de una fotografía. (Schaeffer, 1990) La imagen en movimiento registra el tiempo en su duración y no en su fragmentación al contrario que la fotografía, pero mantiene la condición de huella, del momento de la impresión. Como índices no significan nada sino que denota al objeto por sus características, ya que este estadio de la imagen tiene que ver con la práctica (con el arché) y no con la semántica.

Sin embargo, su inscripción dentro de la película convierte las imágenes en signos doblemente convencionales. Es decir, con ellas ocurre igual que con las fotografías, que se pueden presenta como index en el sentido postulado por Henri Vanlier (1982). El índice no tiene una intencionalidad ni está codificado pero el index es del orden de los signos, de lo convencional, y demuestra algo para transmitir un mensaje (Schaeffer, 1990).

Por una parte, el archivo tiene la función de remitirnos a elementos de la retórica franquista, es decir a un "sentido oficial" connotativo, presente en el imaginario del receptor, referido a valores del nacionalcatolicismo, a la victoria contra el comunismo, la grandeza de la patria, etc. Pero también podemos identificar en este nivel interpretaciones no ideológicas derivadas de la apelación a sentimientos nostálgicos, al recuerdo del pasado cotidiano de la gente.

Más allá de este primer escalón de connotaciones, la enunciación dispuesta por el realizador a través del montaje y el contrapunto de las canciones abre una nueva vía de interpretación de las imágenes, basada en la ironía. También contribuye a este propósito, por ejemplo, el hecho de tintar las imágenes reales, haciendo explícita la manipulación, buscando el distanciamiento y la sátira.

Es decir, Martín Patino establece a través del montaje un nuevo contrato de significados con el espectador. Es este efecto el que pone en cuestión la retórica histórica del franquismo desde un punto de vista reflexivo, no explícito, al rescribir el enunciado por encima del primer nivel connotativo.

Las propias canciones funcionan de una manera parecida, ya que en primera instancia son canciones preexistentes, pertenecientes a la cultura popular compartida y cargadas de valores que nunca podrían ser censuradas o acusadas de opositoras al régimen. Algunas están más cargadas ideológicamente y otras tienen 
un componente más nostálgico y sentimental, ya que hay desde himnos políticos fascistas hasta flamenco o canciones infantiles.

Pero es su disposición como contrapunto sobre las imágenes la que cambia completamente el sentido, creando un discurso conjunto muy diferente, a veces incluso contrario al que sugerirían individualmente.

En La representación de la realidad Nichols menciona precisamente que el uso de la estrategia reflexiva irónica "suele estar imbuido de una clara conciencia de la tradición" pero plantea problemas éticos ya que tiene que ver con la falta de sinceridad. Además, considera que lo irónico usualmente "está aquejado de un exceso de conocimiento y una deficiencia inventiva (...). Plantea una cuestión incisiva acerca de la propia actitud del autor con respecto a su tema" (Nichols, 1991). Dado que nos atenemos a la teoría de Nichols, que es además, una visión sobre el deber ser del documental, ¿en qué medida podemos hablar de inconvenientes éticos en el planteamiento de Canciones para después de una guerra? La utilización de la estrategia reflexiva irónica por parte de Martín Patino es, en nuestra opinión, su modo de hacer cine político en un contexto dictatorial de represión y censura.

No se trata de mantener una actitud de superioridad sobre los hechos evocados, como criticaba Nichols, sino de poner en cuestión el discurso que el régimen mantiene sobre ellos, en un momento en el que no se puede hacer una crítica pública directa, so pena no solo de arriesgarse a que la obra acabe prohibida sino de enfrentar también un castigo personal.

Más que en la actitud de exceso de conocimiento o en la deficiencia inventiva, el riesgo para este documental recae en la banalización de los hechos y el posible rechazo que ello pueda generar en el espectador. Pero el realizador necesita de hecho generar una reacción de distanciamiento en el que mira respecto a imágenes que son las suyas, las de su propia historia. Juega a favor de Martín Patino la ventaja del tiempo, ya que al referirse mayoritariamente a una España de entre treinta y veinte años atrás, podemos considerar que ha transcurrido el tiempo suficiente como para pedir sin remordimientos éticos al espectador que revise con ojo reflexivo los acontecimientos dolorosos del pasado, con el objetivo de cuestionar el discurso perviviente sobre ellos.

El "saber" del documental

Bill Nichols explica al espectador del documental como actor con la capacidad cognitiva para comprenderlo. Esta que tiene que ver con la experiencia previa y las expectativas, es decir, con un saber del documental: “¿Cuáles son los supuestos y expectativas que caracterizan el visionado de un documental? Hasta el punto en que pueden generalizarse, serán en mayor medida el producto de una experiencia previa que predisposiciones evocadas en el momento". (Nichols, 19991) Según Nichols, los espectadores de este tipo de cine desarrollan capacidades de comprensión e interpretación que les permiten entender las películas, producto de un proceso activo de deducción basado en el conocimiento previo y en el propio texto. El film ofrece apuntes mientras que el espectador propone hipótesis que o son confirmadas o se abandonan.

En ese sentido, el teórico apunta también que esos procedimientos están "íntimamente ligados a cuestiones de ideología" porque en la construcción de la mirada espectatorial rigen muchas de las suposiciones propias acerca de la naturaleza del mundo: qué hay en él, en qué consiste la acción apropiada y qué opciones pueden considerarse legítimamente. 
Pero pese a que están abiertas al cambio, esas prenociones también son "considerablemente capaces" de hacer frente a toda clase de reveses y refutaciones (Nichols, 19991).

En el caso de Canciones para después de una guerra, al trabajar sobre material de archivo ya conocido en su mayoría por el público, los cuestionamientos del receptor no van a girar tanto en torno a la relación de la cámara con el mundo histórico y el resultado que de ello se presenta en la pantalla, sino alrededor del uso particular que de ellas hace el realizador.

Es decir, las inferencias a realizar por el espectador van a necesitar preeminentemente la determinación qué clase de argumentación expone el texto sobre la realidad.

El espectador tiene un primer trabajo de contextualizar el metraje encontrado, las canciones populares y el material de archivo en general dentro del mundo histórico de la España de la posguerra. Martín Patino recurre a una cultura compartida, y al discurso repetido incansablemente por el franquismo, por lo que esta es una parte "sencilla" del trabajo del espectador. Más complejo es el un segundo nivel de interpretación que requiere la película, ya que depende en mucha mayor medida de ese "saber del documental" del que habla Bill Nichols, en una sociedad no acostumbrada a ese tipo de ejercicios, como expondremos a continuación.

Durante la época de la dictadura podemos considerar que la cinematografía documental tuvo muy poco desarrollo (tanto en términos de cantidad como de calidad, relegado prácticamente a la propaganda de la dictadura) y que la relación del público con las imágenes reales estaba muy vinculada a las tradiciones del noticiero y de la propaganda (Rotha, 1936). En España estaban principalmente representadas por el omnipresente Noticiario Documental Cinematográfico franquista (NO-DO). El NO-DO, alejado de pretensiones cinematográficas, fue la memoria del franquismo, uno de sus símbolos más reconocibles y principal vehículo de transmisión de los valores del régimen durante toda la dictadura.

Aunque, sobre todo desde la década de 1960, la cinematografía española también cuenta otros tipos de obras desde largometrajes de finalidad ideológica realizados en el seno del régimen, como Franco, ese hombre (José Luis Sáenz de Heredia, 1964), a incursiones documentales de los autores del Nuevo Cine español- aún hoy, pensar en las imágenes documentales de la España de la dictadura implica recordar automáticamente la sintonía y el tono de la voz en off del NO-DO (Rodríguez, 1999). Este se arrogó la tarea de ser un instrumento de cohesión social y de hecho lo fue, creando un fuerte impacto en el imaginario social que necesariamente influye como prenoción a la hora de consumir otros tipos de discursos documentales.

Por tanto, tenemos una sociedad familiarizada con las imágenes reales en modalidad expositiva pero dentro de un planteamiento sobre la transmisión de la información que responde a los postulados de la teoría del la aguja hipodérmica de Lasswell (Wolf, 1987).

Este paradigma comunicativo, nacido a la luz de los estudios sobre propaganda bélica en los años 20 y 30 , establece una relación directa causa-efecto entre el emisor y el receptor a través del mensaje, en busca de un efecto de manipulación.

Este contexto afecta no solo al espectador común, que en función quizás de su cinefilia y sus posibilidades de acceder a tipos variados de películas o contenidos audiovisuales en general (muy limitadas en la época) podía 
estar más o menos entrenado en otros tratamientos informativos y/o documentales. También impacta sobre la percepción de los propios censores y críticos cinematográficos, especialmente los más adeptos al régimen, ya que su mirada está más ideologizada y rechazan la exposición a otros tipos de discursos.

Cabe precisar que había muchos tipos de censores, por ejemplo a veces era labor de sacerdotes, ya que su posición tenía más que ver con lo moral que con conocimientos cinematográficos.

La relación del público de la época con las imágenes reales no es un hecho banal. Lo que propone Martín Patino no es solo lo contrario de aquello a lo que el espectador está acostumbrado sino que, además, es un pionero en abordar la historia franquista haciendo documental irónico y reflexivo, que guarda mucha más relación con Las Urdes, tierra sin pan, de Luis Buñuel (estrenado en 1933, es decir, referente al periodo anterior a la Guerra Civil y víctima posterior de la censura en España) que con la cinematografía documental española de las décadas del franquismo. Lo hace además con recursos, tanto a nivel de la imagen y como de la música, a los que el espectador sí que está habituado, proponiendo un desafío frente a su recepción habitual.

Canciones para después de una guerra se presenta, en consecuencia, como un ejercicio poco habitual para el público de España, ya que el film necesita de un segundo nivel de lectura, una reflexividad que implica un distanciamiento brechtiano respecto a lo que queda representado para leer más allá del discurso literal, que si no quedaría como un retrato sentimental de la España de la época. Sin embargo, reiteramos de nuevo que hubo importantes críticos de medios fascistas como Pedro Crespo que describieron la película como una "obra de arte ejecutada con un pudor y una minuciosidad increíbles y con una gracia, una ternura, una tristeza, una nostalgia y una alegría vitales: un magnífico exponente de la evolución del país".

La interpretación reflexiva de Canciones para después de una guerra requiere de un cierto conocimiento de las formas y convenciones del documental, como mencionamos que apuntaba Nichols, y subraya la premisa postulada por Comolli acerca de que el documental necesita de un "trabajo más arduo" y "más consciente" por parte del espectador a la hora de fabricar su "mirada" sobre lo que ve en pantalla (Comolli, 2007), si se lo compara con otros tipos de textos audiovisuales, como por ejemplo la dominante propaganda.

En ese esfuerzo extra, en la necesidad de un saber previo sobre el documental y en las prenociones que afectan al espectador cuando se enfrenta a la obra de Martín Patino (sociales, culturales, ideológicas, etc.), en el contexto social concreto de la España de principios de la década de los años 70, encontramos una nueva instancia de posible divergencia respecto a la interpretación del film. No se trata solo de la interpretación del mundo histórico que pone en juego el realizador, de una forma que podemos juzgar más o menos exitosa, sino que depende también de la mirada y el desigual conocimiento del espectador, crítico o censor.

La utilización de imágenes documentales tomadas de otras realidades y el uso de fragmentos de cine de ficción

La relación entre el documental y la ficción es otro de los ejes que atraviesan las principales teorías sobre el cine documental así como la relación de este tipo de cine con el mundo histórico del que busca decir algo.

La película de Martín Patino también está tocada por estas cuestiones ya que puntualmente introduce fragmentos de películas de ficción, sin que haya una diferenciación explícita desde el texto (al margen de una aclaración a posteriori en la parte del final de los créditos, donde se citan los títulos de todas las ficciones 
empleadas). Asimismo, el propio realizador ha confesado además en varias entrevistas que algunas de las imágenes empleadas para hacer su retrato de la España de la posguerra ni si quiera se tomaron en el país, sino que por ejemplo, empleó fotografías de lugares del este de Europa.

La tarea de descubrir si se trata de imágenes del mundo histórico al que se refiere la película o no, o incluso si se trata de escenas ficcionales queda enteramente a merced de las capacidades y la experiencia del espectador y suscita un dilema ético. ¿Es lícito mezclar imágenes de películas de ficción con metraje documental siendo conscientes de que el receptor no puede diferenciarlas? ¿Y utilizar metraje o fotografías tomados de una realidad diferente a aquella de la que se está hablando, buscando deliberadamente que el espectador crea que se trata de imágenes de la misma naturaleza que el resto? ¿En qué sentidos el discurso de Martín Patino permite justificar esas licencias? En cuanto al uso que hace Martín Patino de estos dos tipos de ítems, consideramos que hay dos tipos de intencionalidades, ya que en unos casos es menos explícito que en otros que se trata de imágenes reales de la España de la posguerra (cuando no pasa directamente desapercibido), tanto en cuanto a las escenas de ficción como a imágenes emplazadas para hacerlas pasar falsamente por el mundo histórico que retrata la película.

El primero, ya mencionado en la primera parte de esta monografía, se refiere a aquellos fragmentos en los que podemos distinguir un hiato ficcional en la película y en los que consideramos las escenas ficcionales como documentos culturales. El mejor ejemplo se encuentra en la última parte del film, cuando se confrontan imágenes de Bienvenido Mister Marshall (Luis García Berlanga, 1953) e imágenes de filmes franquistas de temática histórica como Alba de América (Juan de Orduña, 1953). En cuanto a la primera, se trata del fragmento más reconocible de una cinta muy popular en la España de la época y en el segundo caso, la puesta en escena y la temática misma delata claramente el carácter ficcional, dejando escaso margen a posibles confusiones para el espectador.

Este fragmento habla de la llegada de la ayuda económica estadounidense a finales de la década de 1940 y principio de los años 50. Bienvenido mister Marshall es una de las primeras películas abiertamente satíricas con la situación de la España dictatorial y en ella, si bien es controvertido hablar de una influencia del neorrealismo, se atisba ya una inquietud de los realizadores españoles por acercar el cine a la vida cotidiana. Fue por tanto un hito importante dentro del cine español y su uso aparición dentro de Canciones para después de una guerra es una forma de mencionar un episodio histórico dentro de la lógica cronológica que sigue la película, a la vez que refuerza el tono de su propio discurso.

En contraste con este "desembarco" de Estados Unidos en la España franquista, Martín Patino coloca imágenes de una película que evoca el descubrimiento de América, la época de la expansión territorial bajo la corona de los Reyes Católicos. Son fragmentos de films panfletarios habituales en la dictadura que buscan evocar el pasado glorioso de España.

Era una forma más de propaganda del régimen para difundir el sentimiento de orgullo nacional, de grandeza de la patria, como principio vertebral del fascismo falangista y eje de cohesión social.

Con este contraste se pone de nuevo en cuestión el discurso oficial del régimen, que no solo estaba presente en la propaganda documental, sino también en las películas de ficción. 
Dado que este segundo tipo de films monopolizó en gran medida el cine que se hacía en España durante la época de la que habla Canciones para después de una guerra, los fragmentos dan cuenta de una determinada realidad del mundo histórico, que es la realidad de la cultura.

Lo que importa en estos casos no es la historia de ficción que capturaban originalmente esas películas sino lo que representan como documentos de un momento histórico concreto, paradigmáticos culturalmente y cargados de valores sociales. Los fragmentos ficcionales funcionan así del mismo modo que no se pone en cuestión la legitimidad de la aparición de, por ejemplo, un afiche publicitario enmarcado dentro de un enunciado sobre una cierta realidad del mundo histórico.

Además, estas escenas funcionan como sintagmas que constituyen unidades mínimas de significado dentro de una enunciación global, que es la que define el carácter documental de la obra. Como apuntaba el teórico François Niney, es el modo de dirigirse al espectador, es decir, las circunstancias de la enunciación, lo que determina el aspecto más o menos documental, más o menos ficcional, de la obra cinematográfica.

Consideramos que este uso concreto de las escenas de ficción no se relaciona con un interés del autor por desdibujar los límites entre la ficción y el documental en un sentido posmoderno, sino que persigue el objetivo de presentarlas como prueba de una cierta realidad, la cultural. Sin embargo, tampoco podemos dejar de mencionar que la utilización de estas imágenes implica irremediablemente algo de reflexividad sobre los límites del discurso documental y un cierto componente de "cine monstruo" (Comolli, 2007), ya que se convierte en testimonio de cómo el campo de lo imaginario y el campo de lo real se entrecruzan en el cine.

En total, según los créditos de la película, Martín Patino utilizó fragmentos de 22 films de ficción en Canciones para después de una guerra pero cuando aparecen, no en todos los casos su naturaleza es tan evidente como en el caso explicado anteriormente. Es decir, hay fragmentos que para un espectador no exhaustivamente familiarizado con la cinematografía española pueden pasar como fragmentos documentales o, como mucho, recreaciones actuadas específicamente para esta película. Se podría debatir, por ello, sobre si hay un componente de cierta falsedad, de engaño al espectador, de manipulación o al menos de legitimidad cuestionable. Esa misma discusión se presenta a cuando Martín Patino introduce metraje encontrado o fotografías tomadas en situaciones que no son el mundo histórico al que se refiere el documental (la España de la posguerra), haciéndolas pasar por propias de él.

El archivo funciona en este tipo de filmes de complilación como elementos reciclables, como documentos no autorales que cobran sentido al insertarlos dentro de la narración.

Pueden ser usados en muchas enunciaciones diferentes, de forma que cambia su significado.

En ese sentido, importa más la coherencia general del discurso global que la naturaleza particular de cada uno de esos elementos. Como el propio Martín Patino explicaba: Después de una de las proyecciones se me acercó una persona de mediana edad. Me dijo que no había podido evitar las lágrimas en un determinado momento. La razón era que en una determinada escena se había descubierto de niño. No quise desdecirle pero era imposible que en ese fotograma estuviera él, ya que pertenecía a unos noticiarios sobre una ciudad del Este de Europa tomadas al terminar la segunda guerra mundial y que había introducido en la película como si fueran propias de la realidad española. 
No me importaba en esa película, ni en otras que he realizado, la realidad de los hechos. Si, por el contrario, me interesa la coherencia del discurso.

(Fernández Polanco, 2004).

Desde las imágenes de ficción a la propaganda franquista oficial, la publicidad, los fragmentos de noticieros, las simples "tomas" -si utilizamos este término en el sentido en el que Chanan (2007) hablaba del montaje Zapruder-, hasta una imagen de un pueblo de la URSS colocada como si se tratase de una localidad española, todos los elementos adquieren un nuevo significado dentro de Canciones para después de una guerra. Lo que importa es esta reescritura, esta reinscripción, a la que quedan subordinados todos los elementos del discurso que propone la película, en busca de una memoria reflexiva y no tanto objetiva.

Todas estas consideraciones también apuntan de nuevo a que Canciones para después de una guerra requiere de un tipo de visionado complejo, de un esfuerzo de interpretación de los diferentes matices por encima de la media de lo que el espectador, el crítico o el censor estaban acostumbrados a enfrentar dado el precario estado de desarrollo de la cinematografía documental española.

\section{Conclusiones}

Con este repaso a las relaciones de Canciones para después de una guerra con algunas problemáticas transversales a la imagen y la cinematografía documental, hemos querido establecer algunos de los parámetros en los que la lectura del film supone un esfuerzo de comprensión. Su interpretación no es intuitiva, requiere un trabajo de distanciamiento y depende de las prenociones sobre lo documental del espectador, su ideología y su experiencia particular. Es decir, está afectada por la eficacia del discurso y el dispositivo planteado por Martín Patino, pero también por factores externos al propio filme.

Así, hemos identificado esta película dentro de la taxonomía postulada por Bill Nichols e indicado que no podemos ubicarla dentro de una sola modalidad, como una forma pura, al igual que ocurre con el cine documental en general. Este factor se explica al considerar la imagen tomada de la realidad no solo como un índice, como una huella, sino como un index sometido a codificaciones enunciativas en dos niveles diferentes, uno más intuitivo, popular, y una reescritura de significado propuesta por Martín Patino. También el tipo de recursos utilizados, tanto a nivel de imagen como a las propias canciones encargadas de llevar el peso del texto, y su relación con el mundo histórico condicionan la interpretación más crítica, sentimental o superficial del film por parte del receptor.

Además, cabe resaltar que el realizador siempre prima la coherencia global de su discurso a la hora de realizar el montaje y es sobre este nivel sobre el que es pertinente plantear la ética del documental.

En nuestra opinión, no es el "fracaso" del realizador lo lleva a que determinados espectadores, críticos o censores interpretasen la película de un modo opuesto al que persigue la argumentación de Martin Patino. Por el contrario, ello depende de las implicaciones de la naturaleza de la imagen documental y, más en concreto, de este tipo de discurso cinematográfico, en un contexto de recepción también determinado histórica, cultural, social y políticamente. De hecho, incluso podríamos suponer en Martín Patino la voluntad de crear un discurso 
que juegue con la ambigüedad, ya que esta una de las pocas vías de escape posibles ante la censura y la represión de la dictadura.

De hecho, la ambigüedad y la ironía son estrategias utilizadas por él anterior mente en películas de ficción (por ejemplo, la emblemática Nueve cartas a Berta, 1965), al igual que por otros autores del movimiento conocido como Nuevo Cine Español. Estos, en el terreno de lo ficcional, aportaron obras muy críticas con la dictadura mucho antes de que el documental asumiera posturas políticas, con Basilio Martín Patino a la cabeza y con la obra aquí analizada como pionera y principal exponente.

Por supuesto, al hablar en estos términos estamos haciendo generalizaciones sobre los motivos por los que cada una de las personas que interpretaron el film de forma diferente es su época. Como toda generalización puede ser injusta y equivocada si examinamos cada caso particular, pero no nos parece vano ni insustancial realizar una aproximación teórica de este tipo ya que si hablamos de esta película como un documental, lógicamente va a estar atravesada por problemáticas paradigmáticas a este tipo de cinematografía y ello tiene consecuencias también en su recepción.

El fenómeno de las interpretaciones contrarias ocurre con este film concreto y en unas circunstancias particulares pero hablar de él también contribuir al debate general sobre el estatuto del discurso y la imagen documental.

Bibliografía

Arroyo Corral, M. A. (2010). Canciones para después de una guerra. Madrid: ITE (Instituto Nacional de Tecnologías Educativas y de Formación del Profesorado).

Barthes, R. (1982). Retórica de la imagen, en L'obvie et l'obtus. Essais critiques III. París: Seuil. Castro de Paz, J. L y Pena Pérez, J. J. (2005). Cine español, otro trayecto histórico. Valencia: Ediciones de la Filmoteca-Instituto Valenciano de Cinematografía.

Català, J. M., Cerdán, J. y Torreiro, C. (2001). Imagen, memoria y fascinación, Notas sobre el documental en España. Madrid: Ocho y medio.

Cerdán, J. y Torreiro, C. (2005). Documental y vanguardia. Madrid: Cátedra.

Chanan, M. (2007). The Politics of Documentary. Londres: British Film Institute.

Comolli, J. L. (2004). Ver y poder. La inocencia perdida: cine, televisión, ficción, documental. Buenos Aires: Aurelia Rivera, 2007.

Dubois, P. (1994). El acto fotográfico. Barcelona: Paidós, 1997.

Fernández Polanco, A. (2004). Montaje, ficción y umbral de realidad. Dos lecturas: "Direct indirect" de y "Casas viejas. El grito del Sur" de Basilio Martín Patino. Hipótesis Para Una Investigación. Madrid: Reunión Científica 2004 Universidad Complutense. 
Galán, D. (2003). Una película única. Reportaje publicado en Madrid: diario El País 31 de mayo de 2003.

Gubern, R. (2009). Historia del cine español. Madrid: Cátedra.

Nichols, B. (1981). Ideology and the image. Social Representation in the Cinema and Other Media. Indiana: Bloomington-Indiana University Press.

Nichols, B. (1991). La representación de la realidad. Cuestiones y conceptos sobre el documental. Barcelona: Paidós.

Niney, F. (2009). Le documentaire et ses faux semblants. París: Klincksieck.

Niney, F. (2002). L'épreuve du reel à l'écran. Essai sur le principe de réalité documentaire. Bruselas: De Boeck.

Nichols, B. (2001). Introduction to documentary. Indiana: Indiana University Press.

Rodríguez, S. (1999). NO-DO Catecismo social de una época. Madrid: Ed. Complutense.

Rotha, P. (1936). Documentary Film. The use of the film medium to interpret creatively and in social terms the life of the people as it exists in reality. Londres: Faber and Faber.

Schaeffer, J. M. (1990). La imagen-precaria. Del dispositivo fotográfico. Madrid: Cátedra. Tranche, R. y SánchezBiosca, V. (2001). NO-DO El tiempo y la memoria. Madrid: Ed. Cátedra-Filmoteca Española.

Vanlier, H. (1982). La rhétorique des index. En Cahiers de la photographie, número 5.

Wolf, M. (1987). La investigacion de la comunicacion de masas. Critica y perspectivas. Barcelona: Paidós Ibérica.

Abstract: This article proposes a theoretical approach to the documentary Songs after the war (1971) directed by the spanish film-maker Basilio Martín Patino during the last years of Franco regime. In this film, the director portraits the post-war in Spain through archive images and popular songs. From concepts developed by some of the main thinkers of documentary cinema, the article aims to contribute with new theoretical considerations in the explanation of a curious phenomena: there was no agreement in determine if the film supported Franco regime or not. The specificity of the documentary image, the reflective speech of Patino in oposition to the apparent exposition and the extra effort for the interpretation that demands this film compared to the mass cinema of those years are some of the factors that present several difficulties in the organic reception of the film.

Key words: Basilio Martín Patino - After-war songs - Franquism - Spain - documentary - reflection.

Resumo: Este artigo é uma aproximação teórica ao documental Canções para depois de uma guerra (1971), filmado pelo realizador espanhol Basilio Martin Patino durante os anos finais do franquismo. Neste filme, o diretor faz um retrato da Espanha de pós-guerra através de imagens de arquivo e canções populares. A partir dos conceitos desenvolvidos por alguns dos principais pensadores do cinema documental, se procura aportar novas considerações, num sentido puramente teórico, que contribuam a explicar um fenômeno curioso ocorrido 
em sua recepção crítica e na avaliação para sua censura: não havia acordo se era um filme anti-franquista ou não. As especificidades da imagem documental, o discurso reflexivo de Patino oposto a uma aparente exposição e o esforço extra de interpretação que requer este filme em comparação com o cinema que tinha a seu acesso na época a média do público são alguns dos fatores que abrem, nossa opinião, uma gama de dificuldades de recepção orgânicas ao filme, prévias à visão do espectador.

Palavras chave: Basílio Martín Patino - Canções para depois de uma guerra - franquismo - Espanha documental expositivo - reflexividade.

La doble lectura de Canciones para después de una guerra explicada desde el marco teórico de las problemáticas del documental fue publicado de la página 29 a página42 en Cuadernos del Centro de Estudios de Diseño y Comunicación Nº 62 